\title{
Uticaj mikroorganizama na starenje vodozahvatnih objekata odabranih pojava mineralnih voda Srbije
}

$\mathrm{R}$ azvoj mikroorganizama je veoma česta pojava u konstruisanim sistemima, te tako i u vodozahvatnim objektima podzemnih (mineralnih) voda, koji mogu biti uzročnici ozbiljnih problema za rešenje inženjerskih poduhvata, obzirom da je poznato da doprinose razvoju ili ubrzavanju korozije, tj. procesu poznatom kao biokorozija ili mikrobiološki indukovana korozija [1 - 4]. Proizvodi metabolizma mikroorganizama, kao što su enzimi koji su aktivni unutar matrice egzopolisaharida, te organske ili neorganske kiseline, ispraljiva jedinjenja, kao što su $\mathrm{NH}_{3}$ ili $\mathrm{H}_{2} \mathrm{~S}$, deluju na metalne konstrukcije [5] izazivajući fizičku degradaciju materijala, čija sanacija uzrokuje ozbiljne finansijske gubitke.

\section{1}

\section{Uvod}

Poznato je da je korozija metalnih konstrukcija uzrokovana mikroorganizmima pitanje od velikog interesa za mnoge industrije, od proizvodnje nafte/gasa do distribucije pitke vode. Procenjuje se da ublažavanje korozije košta 3\% bruto svetskog društvenog proizvoda - približno 1.9 triliona dolara godišnje. Uz to, mikrobiološka korozija je dokumentovana za sve vrste metala i legura koji su trenutno u upotrebi, sa mogućim izuzetkom titanijuma, a razvoj mikroorganizama primetan je u laminarnim, kao i u turbulentnim uslovima režima tečenja podzemnih (mineralnih) voda. Uz to, gvožđeviti materijali poguduju intezivnijem razvoju mikroorganizama u odnosu na PVC cevi i sl. [5 - 8].

U slučaju korišćenja subhidrogeotermalnih podzemnih vodnih resursa i uticaja specifičnog mikrobiološkog diverziteta, dolazi do smanjenja topltotne efikasnosti termotehničke opreme, odnosno, do smanjenja toplotne i masene efikasnosti rashladnih uređaja, u slučaju korišćenja vodnih resursa u rashladne svrhe [9].

Takođe, sa razvojem mikrobioloških procesa dolazi i do formiranja nerastvornih hemijskih jedinjena, pri čemu je česta pojava taloženje kalcijum-karbonata u uslovima eksploatacije mineralnih voda, te oksihidroksida gvožđa, silicijum-dioksida, jedinjenja mangana, fosfata, sumpora i sl., čime dolazi do začepljenja cevi, odnosno, do opadanja eksploatacionih kapaciteta vodozahavta i njihovog isključenja iz upotrebe [10 - 12]. Smatra se da je $80 \%$ naslaga inkrustacije mikrobiološkog porekla $[8,13]$.

Iz prethodno navedenih razloga, tokom 2017/18. godine, obavljena je procena uticaja mikrobiološkog diverziteta odabaranih pojava mineralnih voda Srbije na starenje vodozahvata i pratećih tehničkih objekata u uslovima eksploatacije, sa mogućnošću višenamenskog iskorišćavanja mineralnih voda u balneoterpijske svrhe, svrhe flaširanja (pića), te kao potencijalni hidrogeotermalni resurs, itd.

\section{Oblast istraživanja}

Pojave mineralnih voda koje su predmet istraživanja nalaze se na teritoriji Republike Srbije, u različitim hidrogeološkim i geotektonskim celinama, na području najstarijeg kopna Balkanskog poluostrva, tj. Srpskog kristalastog jezgra (pojava u Lomnici), dok se pojava u Selters banji vezuje se za obodne delove Panonskog basena, nekadašnjeg epikontinentalnog mora Paratetisa (Slika 1).

Mineralne vode formiraju se u intergranularnoj poroznoj sredini sa slobodnim nivoom, u izdani predstavljenoj petrografskim varijetietima peščara, konglomerata, glina i tufita neogene starosti na području Lomnice, u čijoj podini se nalaze gornjokredne flišne tvorovine i prekambijumski kristalasti škriljci (gnajsevi, kvarciti, amfiboliti) sa interklacijama granitoida kao uzročnika povišenog sadržaja $\mathrm{CO}_{2}$ u mineralnim vodama. Pukotinsko-disolucioni tip izdani sa nivoom pod pritiskom formiran je u matriksu sedimenata krednog fliša Selters banje, gde su masivni i tektonski oštećeni donjokredni krečnjaci, sa pukotinama duž kojih su se razvili procesi karstifikacije, poznati kao značajni vodonosnici mineralnih voda [14 - 19] (Slika 1).

\section{$3 \quad$ Materijali i metode}

Uz prethodno poznavanje fizičko-hemijskih karakteristika mineralnih voda, i imajući u vidu predmet istraživanja i postavljene zahteve, izvršeno je uzorkovanje mineralnih voda za mikrobiološke analize primenom BART biodetektora i metagenomske analize mikrobioma mineralnih voda, tehnikama sekvenciranja naredne generacije na osnovu 16S rDNA gena.

\subsection{Uzorkovanje mineralnih voda za mikrobiološke analize}

Uzorkovanje mineralnih voda iz vodozahvatnih objekata obavljeno je pomoću posebne opreme (boce za dubinsko uzimanje uzoraka), sa dubine od $50 \mathrm{~cm}$ ispod površine vode. Potom su uzorci kolektovani i transportovani u skladu sa standardima SRPS EN ISO - 19458:2009, u čistim staklenim bocama zapremine 250 mL i 1000 $\mathrm{mL}$, koje su prethodno sterilisane u suvom sterilizatoru na temperaturi od $433-453 \mathrm{~K}\left(160-180^{\circ} \mathrm{C}\right)$, u trajanju od jednog sata. 


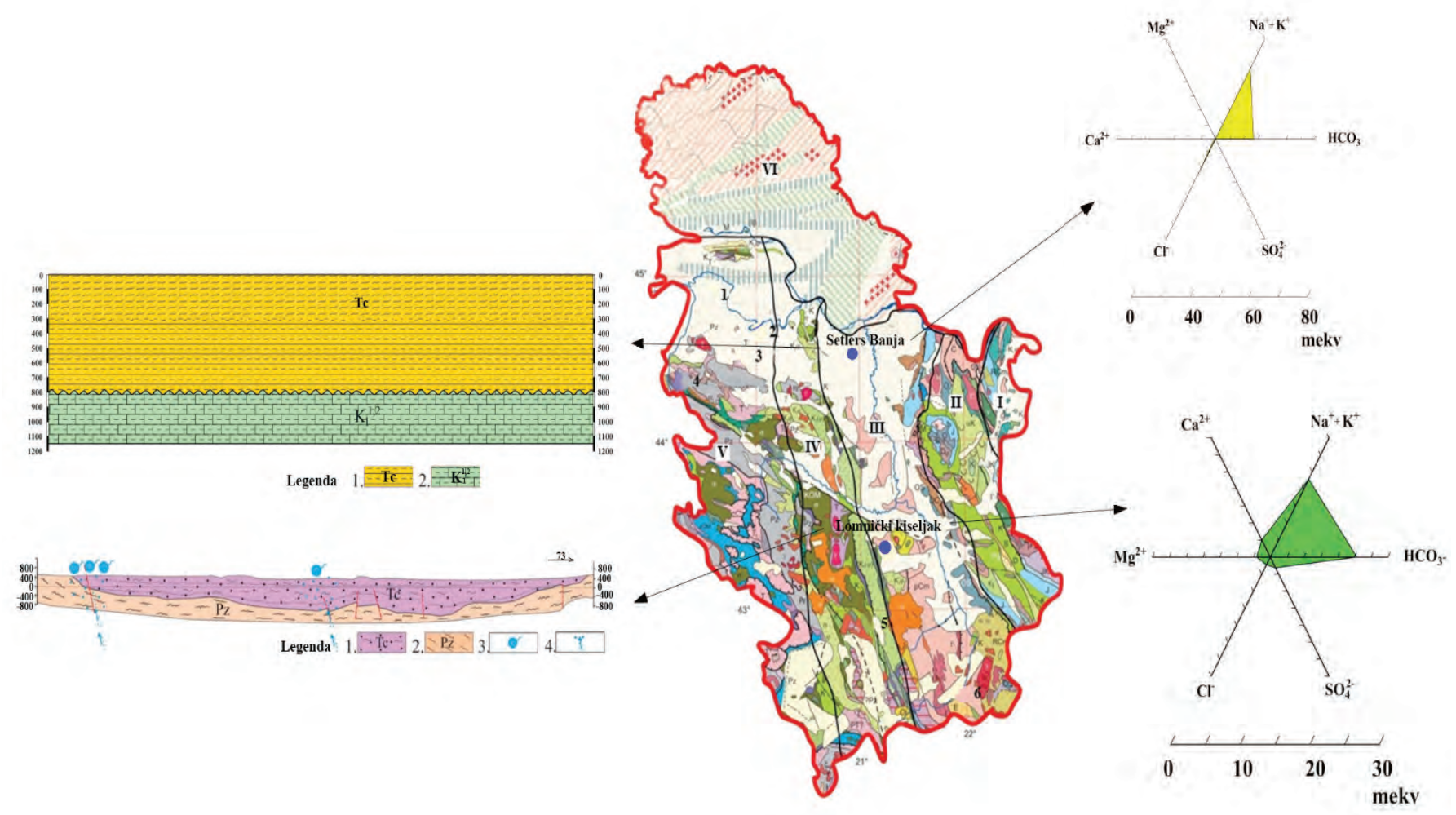

Slika 1: Geotektonski položaj istraživanih pojava mineralnih voda sa prikazom geološke podloge teritorije Srbije, te prikazom geoloških profila istraživanih pojava i njihovog osnovnog jonskog sastava.

Legenda: I - Dakijski basen; II-Karpato-balkanidi; III - Srpsko kristalasto jezgro; IV- Šumadijsko kopaonički blok; V-Unutrašnji Dinaridi zapadne Srbije; VI-Panonski basen;

Selters banja: 1. Tercijarni sedimenti: glinovito-peskoviti litološki članovi sa proslojcima uglja (lignita); 2. Laporci, peščari i krečnjaci kredne starosti;

Lomnički kiseljak: 1 - Vodopropusne nevezane prekvartarne naslage; 2 - Pretežno vodonepropusne visokometamorfne stene; 3 -Zona isticanja ugljokiselih voda; 4 - Pravac migracije ugljen-dioksida.

\subsection{BART analize}

Mineralne vode Selters banje analizirane su na prisustvo različitih ekofizioloških grupa bakterija primenom BART biodetektora. Određivano je prisustvo gvožđevitih, sulfatoredukujućih, heterotrofnih aerobnih i fakultativno anaerobnih, denitrifikacionih i heterotrofnih bakterija koje imaju sposobnost produkcije ekstracelularnih polimernih materija primenom IRB (eng. Iron Related Bacteria), SRB (eng. Sulfate Reducing Bacteria), HAB (eng. Heterotrophic Aerobic Bacteria), DN (eng. Denitrifying Bacteria) i SLYM (eng. Slime Forming Bacteria) BART sistema. U svim pojavama, određivano je i prisustvo fluorescentnih Pseudomonas vrsta (P. aeruginosa i P. fluorescens) primenom FLOR BART biodetektora. Uzorci su inkubirani na temperaturi od $22{ }^{\circ} \mathrm{C}$, u standardnom propisanom vremenskom periodu za svaki biodetektor. Tokom perioda inkubacije uzoraka $(5,10$ do 15 dana u zavisnosti vrste primenjenog biodetektora), signaturne reakcije bakterijske aktivnosti i njihovih metaboličkih proizvoda, praćene su dnevno i fotografisane su za fotodokumentaciju i proveru pojave vremena i tipa reakcija prateći proceduru datu u priloženoj literaturi.

\subsection{Metagenomske analize}

Utvrđivanje mikrobiološkog diverziteta mineralnih voda Lomnice obavljeno je izvođenjem metagenomskih analiza mikrobioma, tehnikama sekvenciranja naredne generacije (eng. Next Generation Sequencing - NGS), molekularnom identifikacijom na osnovu 16S rDNA gena, predstavljajući najviši nivo identifikacije mikroorganizama, čime je omogućena njihova klasifikacija prema različitim taksonomskim kategorijama: razdeo, klasa, red, porodica i rod. DNK mikroorganizama ekstrahovana je membranskom filtracijom, pri čemu je provera uzorka obavljena horizontalnom elektroforezom, uz merenje koncentracije DNK uzoraka pomoću Qubit Fluorometric Quantitation uređaja. Izvršena je i priprema bilioteka amplikona dobijenih sekvenciranjem 16S rDNA gena korišćenjem Illumnia protokola na MiSeq sekvenceru. Uz procenu biodiverziteta, određen je alfa diverzitet kako bi se utvrdila raznolikost i bogastvo opaženih taksonomskih kategorija u ispitivanom uzorku mineralne vode. 


\section{PT Inženjerska praksa}

\section{$4 \quad$ Rezultati i diskusija}

$\mathrm{Na}$ osnovu fizičko-hemijskih karakteristika mineralnih voda, zaključeno je da pojava u Selters banji pripada natrijumsko bikarbonatnim hloridnim fluoridnim hipertermama, neutralnim ( $\mathrm{pH}$ 6.9) i mineralizovanim vodama $(7300 \mathrm{mg} / \mathrm{L})$, dok mineralne vode Lomničkog kiseljaka pripadaju natrijumsko bikarbonatnim ugljokiselim hladnim $\left(14^{\circ} \mathrm{C}\right)$ i mineralizovanim vodama, koje u zavisnosti od spoljnih hidroloških uslova karakteriše sadržaj rastvorenih soli od $2500-6700 \mathrm{mg} / \mathrm{L}$, kao posledica hidrauličke povezanosti freatske izdani i površinskih voda. Odlikuju ih i izuzetno povišene koncentracije farmakološko-terapeutsko aktivnih mikrokomponenata: F- (3.0 mg/L), Br (5.0 mg/L), Li ${ }^{+}(7.20 \mathrm{mg} / \mathrm{L})$, $\mathrm{Rb}^{+}(1.56 \mathrm{mg} / \mathrm{L})$ i $\mathrm{Sr}^{2+}(2.0 \mathrm{mg} / \mathrm{L})$ (Selters banja), odnosno, izuzetno visoke vrednosti sadržaja CO2 (2000 mg/L) u mineralnim vodama Lomničkog kiseljaka [14 - 17] (Tabela 1).

Tabela 1. Rezultati fizičko-hemijskih analiza istraživanih pojava mineralnih voda.

\begin{tabular}{|c|c|c|c|c|c|}
\hline $\begin{array}{l}\text { Ispitivani } \\
\text { parametri }\end{array}$ & $\begin{array}{l}\text { Selters } \\
\text { banja }\end{array}$ & Lomnica & $\begin{array}{l}\text { Ispitivani } \\
\text { parametri }\end{array}$ & $\begin{array}{c}\text { Selters } \\
\text { banja }\end{array}$ & Lomnica \\
\hline \multicolumn{3}{|c|}{ OSNOVNE KARAKTERISTIKE } & \multicolumn{3}{|c|}{ MAKROKOMPONENTE (mg/L) } \\
\hline $\mathrm{T}\left({ }^{\circ} \mathrm{C}\right)$ & 40 & 14 & $\mathrm{Na}^{+}$ & 2360.0 & 500.0 \\
\hline $\mathrm{pH}$ & 6.9 & 6.5 & $\mathrm{~K}^{+}$ & 55.0 & 28.0 \\
\hline $\mathrm{M}(\mathrm{mg} / \mathrm{L})$ & 7300 & $2500-6700$ & $\mathrm{Ca}^{2+}$ & 60.0 & 100.0 \\
\hline$E(\mu S / c m)$ & 12000 & 9571 & $\mathrm{Mg}^{2+}$ & 80.0 & 49.0 \\
\hline \multicolumn{3}{|c|}{ RADIOAKTIVNOST } & $\mathrm{HCO}_{3}^{-}$ & 3360.0 & 1586.0 \\
\hline $\mathrm{Rn}(\mathrm{Bq} / \mathrm{L})$ & 20.3 & 7.8 & $\mathrm{SO}_{4}^{2-}$ & 2.0 & 139.0 \\
\hline $\mathrm{Ra}(\mathrm{Bq} / \mathrm{L})$ & 0.52 & 0.18 & $\mathrm{Cl}^{-}$ & 1560.0 & 85.0 \\
\hline $\mathrm{U}(\mathrm{mg} / \mathrm{L})$ & 0.0004 & 0.0007 & $\mathrm{NO}_{3}^{-}$ & 0.0 & l \\
\hline \multicolumn{6}{|c|}{ MIKROKOMPONENTE (mg/L) } \\
\hline $\mathrm{F}^{-}$ & 3.0 & 0.2 & $\mathrm{Cu}^{+}$ & 0.005 & 0.012 \\
\hline $\mathrm{Br}$ & 5.0 & 0.02 & $\mathrm{Zn}$ & 0.030 & 0.040 \\
\hline J & 0.90 & 0.04 & $\mathrm{~Pb}^{+}$ & 0.003 & 0.080 \\
\hline $\mathrm{Li}^{+}$ & 7.20 & 2.20 & $\mathrm{Cd}^{2+}$ & 0.0005 & 0.0020 \\
\hline $\mathrm{Rb}^{+}$ & 1.56 & 0.07 & $\mathrm{Ni}^{2+}$ & 0.003 & 0.003 \\
\hline $\mathrm{Sr}^{2+}$ & 2.0 & 1.75 & $\mathrm{Hg}$ & 0.0002 & 0.0002 \\
\hline $\mathrm{Cr}$ & 0.010 & 0.028 & $\begin{array}{c}\text { Slobodan } \\
\mathrm{CO}_{2}\end{array}$ & 0.34 & 2000 \\
\hline
\end{tabular}

Legenda: $\mathrm{T}$ - Temperatura; $\mathrm{M}$ - Mineralizacija; E Elektroprovodljivost; / - Nije određena vrednost parametra.

Sa aspekta sadržaja specifičnih biocenoza u mineralnim vodama Selters banje i uticaja na radni vek vodozahvatnih objekata, detektovana je populacija sulfatoredukujućih i aerobnih sluz produkujućih bakterija, dok biohemijska aktivnost ostalih fizioloških grupa mikroorganizama tokom testiranja u standardnom previđenom Lag periodu nije bila od značaja za optimalni period eksploatacije vodozahvata. Detaljnim osmatranjem signaturnih rekacija u SRB
BART biodetektoru, zabeležena je umerena biohemijska aktivnost sulfatoredukujućih bakterija, koje koristeći sulfate kao elektron akceptore u razgradnji organskih materija kao donora, generišu gas $\mathrm{H}_{2} \mathrm{~S}$. Crni talog gvožđe sulfida, formiran usled redukcije sulfata, uzorokuje promenu boje mineralnih voda, bunarskih elemenata (filtera, eksploatacionih kolona, potisnih vodova i sl.), kao i pratećih tehničkih objekata (cevovoda, toplotnih pumpi, i sl.). Uz to, kao posledica prisustva gasa $\mathrm{H}_{2} \mathrm{~S}$ dolazi i do promene mirisa mineralnih voda (miris na ,pokvarena jaja”), a ujedno, gas $\mathrm{H}_{2} \mathrm{~S}$ inhibira i razvoj rupičasto fokusirane korozije. Uz prisustvo sulfatoredukujućih bakterija, detektovana je i populacija aerobnih bakterija sposobnih za sintezu ekstracelularnih polimernih suspstanci na pumpama, filterima, eksploatacionim kolonama, itd., sa malom brojnošću planktonskih potencijalno aktivnih ćelija, koje mogu da proizvode pigmente. Тако, boja biofilma je indikator i karakterističnih vrsta mikroorganizama (na primer, crvena boja je indikator vrsta Serratia marcescens, odnosno, ljubičasta boja je indikator vrsta Chromobacterium ili Janthinobacterium species). Crna boja, osim što može biti indikator vrsta sulfatoredukujućih bakterija (na primer, rod Desulfovibrio), može biti i indikator taloženja karbonata na bunarskim elementima. Usled razvoja procesa biološkog kolmiranja, tehnički elementi vodozahvata na kojima se razvijaju biofilmovi zadobijaju karakterističnu boju u zavisnosti od vrsta specifičnih zajednica u biofilmu, koji doprinose povećanom bakterijskom nivou u vodi, smanjuju rastvoreni kiseonik, uzrokuju promenu ukusa, mirisa, zamućenje vode, te pospešuju hidrauličku grubost i doprinose razvoju procesa korozije. Sa druge strane, novije studije su pokazale da su biofilmovi u stanju da suzbiju proces korozije, jer pojedine vrste bakterija koriste hemijske elemente, npr. kiseonik, koji je potreban da se reakcija korozije nastavi [8, 17, 20 - 24].

Takođe, biofilmovi deluju i kao „sigurna utočišta” za patogene sojeve bakterija, kao što je Escherichia coli, Pseudomonas i Legionella, omogućavajući njihov opstanak i dalju reprodukciju, čiji sastav zavisi i od fizičko-hemijskih karakteristika materijala na kome se biofim razvija, s obzirom da različite bakterijske vrste kolonizuju i različite materijale $[25,26]$.

Korišćenjem softverskog programa BART-Soft v6, na primeru mineralnih voda Selters banje, ustanovljen je rizik od razvoja procesa biokorozije i biološkog kolmiranja vodozahvata, zbog čega postoji potreba za tretmanom remedijacije mineralnih voda, a usled prisustva specifičnih grupa bakterija, postoji i minimani zdravstveni rizik prilikom korišćenja mineralnih voda u balneoterapijske svrhe i svrhe pića (flaširanja) [17].

Sa ciljem implementacije što većeg broja različitih metodoloških postupaka i njihove primene u hidrogeologiji, na uzorcima mineralnih voda Lomnice izvedene su metagenomske analize mikrobioma, kako bi se standardna hidrogeološka metodologija, uz postojeću primenu BART testova, upotpunila inovativnim metodama ispitivanja mineralnih voda, čime je ustanovljen bogat alfa diverzitet ispitivanih uzoraka. Najzastupljenija taksonomska kategorija bila je familija Rhodobacteraceae sa više od 56\% zastupljenosti, za koju je karaktristično stanište vodena sredina [27], te tako i mineralne vode 
sa povišenim sadržajem $\mathrm{CO}_{2}$. Takođe, ostale familije (Gallionellaceae i Burkholderiaceae) iz klase Gammaproteobacteria bile su prisutne sa $1.5 \%$ i $3.4 \%$. Poznato je da se familija Gallionellaceae sastoji od roda Gallionella sa jednom ustavljenom vrstom Gallionela ferruginea [28], koja je tipičan stanovnik podzemnih (mineralnih) voda, i razvija se na tehničkim elementima vodozahvata (filterima, pumpama, potisnim vodovima, eksploatacionim kolonama), nalazeći se mnogo ređe u planktonskom stanju. Ova vrsta doprinosi stvaranju naslaga koje u svom sastavu mogu sadržati i karbonate i sulfide sa visokim sadržajem $\mathrm{Fe}^{3+}$ i visokom brojnošću populacije gvožđevitih bakterija. Formirani produkti, osim što negativno utiču na površinske karakteristike materijala, uz istovremeni razvoj i procesa biokorozije, utiču negativno i na organoleptičke karakteristike mineralnih voda [20]. Takođe, u ispitivanom uzorku mineralnih voda, zanimljivi rezultati sa relativnom zastupljenošću više od $1 \%$ dobijeni su za rodove: Maritimimonas (5.8\%), Phreatobacter (4.2\%), Planktosalinus (2.7\%), Acinetobacter (1.5\%), Geminocystis (1.2\%) i Sulfuritalea (1.1\%) [29].

Izvesno je da identifikovani mikroorganizmi mineralnih voda Lomnice mogu da učestvuju u različitim mikrobiološkim procesima u vodozahvatu, čije manifestacije životnih aktivnosti uzrokuju brojne inženjerske probleme u uslovima eksplotacije i višenamenskog iskorišćavanja vodnog resursa, sa aspekta kvalitativnih svojstava mineralnih voda, te stanja funkcionalosti tehničkog objekta.

\section{$5 \quad$ Zaključak}

Rezultati istraživanja su pokazali da odabrane pojave mineralnih voda karakteriše prisustvo jedinstvenog mikrobiološkog diverziteta koji uspešno podnosi specfične uslove mineralnih voda, u smislu povišenih vrednosti sadržaja rastvorenih soli, temperature, ugljen-dioksida, itd., zbog čega je izvesno je da isti treba da bude predmet analize u uslovima projektovanja i održavanja sistema namenjenih za eksploataciju, transport i distribuciju voda. Neophodno je detaljno proučavanje interakcija mineralne vode $\leftrightarrow$ mikroorganizmi $\leftrightarrow$ materijali, ukoliko se ima za cilj dugotrajna eksploatacija bez negativnih efekata na radni vek tehničkih objekata i korisnika vodnih resursa.

\section{Literatura}

[1] Beech, I. B., Sulphate-reducing bacteria in biofilm on metallic materials and corrosion, Microbiology Today, 30 (2014), pp. 115117.

[2] Little, B. J., J. S. Lee, \& R. I. Ray, The influence of marine biofilms on corrosion: a concise review, Electrochimica Acta, 54 (2008), 1, pp. 2-7.

[3] Belkaid, S., M. A. Ladjouzi, \& S. Hamdani, Effect of biofilm on naval steel corrosion in natural seawater, Journal of Solid State Electrochemistry, 15 (2001), 3, pp. 525-537.

[4] Wang, H., C. Hu, C., X. Hu, M. Yang, \& J. Qu, Effects of disinfectant and biofilm on the corrosion of cast iron pipes in a reclaimed water distribution system, Water research, 46 (2012), 4, 1070-1078.

[5] Beech, I. B., \& J. A. Sunner, Biocorrosion in drinking water distribution systems, Interface Science and Technology, 10 (2006), 14, pp. 245-255.

[6] Koch, G. H. Corrosion Cost and Preventive Strategies in the United States, Report by CC Technologies Laboratories, Inc. to Federal Highway Administration (FHWA), Office of Infrastructure Research and Development, 2001. http://www.corrosioncost.com/pdf/ main.pdf.

[7] Little, B. J., \& P. Wagner, An overview of microbiologically influenced corrosion of metals and alloys used in the storage of nuclear wastes, Canadian Journal of Microbiology, 42 (1996), 4, 367-374.

[8] Šaraba, V., O. Krunić, V. Obradović, Primena BART biodetektora u metodologiji hidrogeoloških istraživanja mineralnih voda, 17. Kongres geologa Srbije, Srpsko geološko društvo, Beograd, Srbija, 2018.

[9] Center for Biofilm Engineering, Montana State University, 366 Barnard Hall, P. O. Box 173980, Bozeman, MT 59717-3980, 2017. http://www.biofilm.montana.edu/index.html.

[10] Houben, G., Well ageing and its implications for well and piezometer performance, IAHS publication, 2001.

[11] Houben, G., C. Treskatis, Water well rehabilitation and reconstruction, McGraw-Hill, 2007.

[12] Konhauser, K. O., Introduction to geomicrobiology, John Wiley \& Sons, 2009.

[13] Schnieders, J. H., Chemical cleaning, disinfection and decontamination of water wells, Johnson Screens, 2003.

[14] Protić, D., Minerane i termalne vode Srbije, Geoinstitut, Beograd, Srbija, 1995.

[15] Filipović, B., Mineralne, termalne i termomineralne vode Srbije, Univerzitet u Beogradu, Rudarsko-geološki fakultet, Beograd, Srbija, 2003.

[16] Marinković, G., Hidrogeološki uslovi formiranja ugljokiselih voda Srbije, Ph. D. thesis, Univerzitet u Beogradu, Rudarskogeološki fakultet, Beograd, Srbija, 2014.

[17] Šaraba, V., O. Krunić, V. Obradović, Mikrobiološki diverzitet termomineralnih lekovitih voda Selters banje - Srbija, 39. Međunarodni stručno-naučni skup „Vodovod i kanalizacija '18“, Savez inženjera i tehničara Srbije, Beograd, Srbija, 2018.

[18] Šaraba, V., O. Krunić, Biohidrogeologija na mestima isticanja odabranih pojava termomineralnih voda Srbije, Zapisnici Srpskog geološkog društva (za 2017. godinu), Srpsko geološko društvo, Beograd, Srbija, 2017.

[19] Geološki Informacioni Sistem Srbije, Geološka karta sa rasporedom listova Osnovne Geološke karte, 1 : 100 000, (Map), Geološki Informacioni Sistem Srbije, Beograd, Srbija, 2012.

[20] Droycon Bioconcepts Inc., Biological Activity Reaction Test BART, User Manual, Saskatchewan, Canada, 2004.

[21] Zuo, R., Biofilms: strategies for metal corrosion inhibition employing microorganisms, Applied microbiology and biotechnology, 76 (2007), 6, pp. 1245-1253.

[22] Stadler, R., W. Fuerbeth, K. Harneit, M. Grooters, M. Woellbrink, W. Sand, First evaluation of the applicability of microbial extracellular polymeric substances for corrosion protection of metal substrates, Electrochimica Acta, 54 (2008), 1, pp. 91-99.

[23] Videla, H. A., \& L. K. Herrera, Understanding microbial in- 
